\title{
PERKEMBANGAN METODE PEMBENIHAN KEPITING BAKAU
}

\author{
Oleh \\ Sandi Permadi ${ }^{1)}$
}

\section{ABSTRACT}

DEVELOPMENT OF MUD CRAB HATCHING METHODS. Indonesia is one of the mud crab exporters. The demand of mud crab products is high, but these products are still dominated by natural catches. Although there are many cultivation efforts, the seeds are still using the catch from nature, which may lead to an unsustainable business. In order to maintain the existing mud crab cultivation business, it is necessary to undertake mass production of crab seeds in an artificial environment, such as in the hatchery or in the laboratory. The research of mud crab larvae maintenance has been carried out in Indonesia since the last four decades, but the results have not been able to produce crab seeds in a mass scale. Therefore, the efforts of hatching crabs in hatcheries must continue for improvement, with techniques and methods should be developed to support sustainable crab enlargement cultivation.

\section{PENDAHULUAN}

Kepiting bakau, Scylla spp. dikenal sebagai makanan yang cukup mewah di restoran-restoran, yang tak kalah lezatnya bila dibanding dengan spesies krustasea lainnya. Menurut FAO-FIGIS dalam Shelley (2008) kebutuhan dunia terhadap bahan pangan kepiting ini terus meningkat dalam kurun waktu 10 tahun (Tabel 1). Nilai budidaya kepiting di Indonesia pada tahun 2005 tercatat sebesar US\$ 9.108 (Tabel 3), yang merupakan urutan ketiga setelah China (US\$ 245.329) dan Filipina (US\$ 30.775). Di Indonesia, kepiting bakau merupakan produk perikanan unggulan dari Kementerian Kelautan dan Perikanan (Widodo et al., 2010). Volume ekspor kepiting bakau nasional pada awal tahun 1990an mencapai 9000 ton (Cholik \& Hanafi, 1992) dan bisa dipastikan produksinya

\footnotetext{
1) Pusat Penelitian Oseanografi - LIPI
}

meningkat karena konsumsi dalam negeri juga tinggi (Purwati et al., 2012). Pada tahun 2005, volume tangkapan kepiting mencapai 18.750 ton dan volume produksi budidaya sebesar 4.379 ton (FAO-FIGIS dalam Shelley 2008). Sedangkan pada tahun 2009, volume produksi mengalami peningkatan yang signifikan pada angka 28.822 ton dengan nilai produksi mencapai Rp. 506 miliar (Kementerian Kelautan dan Perikanan, 2010). Kemudian pada tahun 2012-2014 volume produksi kepiting budidaya berturut turut sebesar 14.163, 11.898, dan 13.605 ton (Kementerian Kelautan dan Perikanan, 2018). Data produksi tahun 2015 dan 2016 tidak terdokumentasikan pada data statistik yang diterbitkan Kementerian Kelautan dan Perikanan. Kemudian pada tahun 2017 produksi kepiting sebesar 11.573 ton (Kementerian 
Kelautan dan Perikanan, 2018). Data volume produksi pada periode 20122017 menunjukan angka yang fluktuatif, tetapi yang menarik adalah rata-rata nilai eksportnya naik 6,15\% per tahun (Kementerian Kelautan dan Perikanan, 2018). Data tersebut menunjukan bahwa produk kepiting bakau memiliki nilai jual yang terus meningkat, terutama untuk tujuan eksport. Nilai produksi yang terus meningkat tersebut kemungkinan disebabkan permintaan pasar ekspor yang masih sangat besar. Oleh karena itu, peningkatkan volume produksi kepiting bakau perlu untuk ditingkatkan, salah satunya melalui budidaya kepiting bakau yang berkelanjutan.

Pada umumnya, budidaya kepiting oleh masyarakat adalah usaha penggemukan di keramba bambu, usaha kepiting soka di rakit apung, dan pembesaran benih kepiting di tambak (tergantung benih kepiting dari alam) (Agbayani et al., 1990; Cholik \& Hanafi, 1992; Gunarto \& Rusdi, 1993; Trino et al., 1999; Trino \& Rodriguez, 2001; Mwaluma, 2002; Purwati et al., 2009). Penelitian pemeliharaan burayak atau larva kepiting telah dilakukan baik di mancanegara maupun di indonesia, Negara-negara tersebut antara lain: Malaysia (Ong, 1964), Hawai, USA (Brick, 1974), Afrika Selatan (Hill, 1974), Australia (Heasman \& Fielder, 1983) dan Taiwan (Cowan, 1984). Percobaan pemeliharaan burayak kepiting di Indonesia sudah dimulai sejak tahun 1984 (Wahyuni, 1985; Kasry, 1986; Juwana \& Suprapto, 1992; Yunus et al., 1994). Namun demikian, baru pada periode penelitian 1992/1993 berhasil mencapai tingkat perkembangan Crab I, seperti yang dilaporkan oleh Balai Budidaya Air Payau (Mardjono \& Arifin, 1993), juga pada penelitian kerjasama Puslitbang Oseanologi LIPI (P3O-LIPI) dengan Laboratorium Pengembangan Wilayah Pantai UNDIP di Jepara (Juwana, 1993).

Penelitian pemeliharaan larva kepiting dikembangkan dengan menggunakan probiotik telah dilakukan pada satu dekade terakhir (Balai Besar Riset Perikanan Laut, 2002). Perbaikan teknik produksi benih kepiting bakau (Scylla paramamosain) di Balai Besar Riset Perikanan Budidaya Laut, GondolBali telah berhasil mencapai produksi benih kepiting sebanyak 1637 Crab IV $(5,45 \%)$ dalam waktu 26 hari (Susanto et al., 2006). Percobaan pembesaran benih kepiting hasil hatchery juga mulai dirintis (Rusdi \& Hanafi, 2002; Rodriquez et al., 2007).

Teknik pembenihan kepiting yang telah dipaparkan di atas pada prinsipnya adalah melalui beberapa tahapan, yaitu: (a) penyediaan air laut untuk pembenihan; (b) Penyediaan pakan hidup untuk pemeliharaan burayak (larvae) kepiting; (c) penyediaan induk kepiting memijah: (d) penetasan telurtelur kepiting; dan (e) pemeliharaan burayak kepiting sampai menjadi benih kepiting. Usaha pembenihan kepiting di hatchery-hatchery harus terus digalakan dan dikembangkan teknik, maupun metodenya untuk melestarikan usaha budidaya pembesaran kepiting. 
Tabel 1. Hasil tangkap Scylla serrata dalam ton (x $1.000 \mathrm{~kg})$.

\begin{tabular}{lrrrrrrrrrrr}
\hline \multicolumn{1}{c}{ NEGARA } & $\mathbf{1 9 9 5}$ & $\mathbf{1 9 9 6}$ & $\mathbf{1 9 9 7}$ & $\mathbf{1 9 9 8}$ & $\mathbf{1 9 9 9}$ & $\mathbf{2 0 0 0}$ & $\mathbf{2 0 0 1}$ & $\mathbf{2 0 0 2}$ & $\mathbf{2 0 0 3}$ & $\mathbf{2 0 0 4}$ & $\mathbf{2 0 0 5}$ \\
\hline Indonesia & 7980 & 7342 & 8298 & 8161 & 8707 & 8774 & 11753 & 11240 & 14802 & 20129 & 18750 \\
Thailand & 5776 & 4243 & 4031 & 3732 & 5736 & 6921 & 5417 & 3823 & 1259 & 2859 & 1865 \\
Filipina & 4835 & 4258 & 1133 & 1124 & 1211 & 1247 & 1604 & 1692 & 1663 & 1466 & 1432 \\
Taiwan & 1339 & 935 & 180 & 215 & 269 & 299 & 230 & 337 & 375 & 9 & 717 \\
Fiji & 234 & 208 & 290 & 270 & 281 & 250 & 268 & 180 & 82 & 324 & 280 \\
\hline
\end{tabular}

Sumber: FAO-FIGIS dalam Shelley (2008).

Tabel 2. Budidaya Scylla serrata dalam ton.

\begin{tabular}{|c|c|c|c|c|c|c|c|c|c|c|c|}
\hline NEGARA & 1995 & 1996 & 1997 & 1998 & 1999 & 2000 & 2001 & 2002 & 2003 & 2004 & 2005 \\
\hline Cina & $\mathbf{0}$ & $\mathbf{0}$ & $\mathbf{0}$ & $\mathbf{0}$ & 0 & $\mathbf{0}$ & $\mathbf{0}$ & 0 & 100870 & 108503 & 111423 \\
\hline Filipina & 2782 & 2463 & 3759 & 4.033 & 4826 & 4968 & 4608 & 4747 & 4809 & 6245 & 6861 \\
\hline Indonesia & 1906 & 1339 & 5176 & 866 & 5143 & 5126 & 3879 & 9039 & 7152 & 2243 & 4379 \\
\hline Taiwan & 1526 & 797 & 430 & 796 & 381 & 315 & 423 & 239 & 226 & 239 & 240 \\
\hline Malaysia & 623 & 381 & 277 & 231 & 188 & 225 & 219 & 311 & 204 & 174 & 162 \\
\hline Thailand & 45 & 132 & 115 & 19 & 9 & 9 & 5 & 10 & 10 & 23 & 20 \\
\hline
\end{tabular}

Sumber: FAO-FIGIS dalam Shelley (2008).

Tabel 3. Nilai budidaya Scylla serrata dalam US\$.

\begin{tabular}{lrrrrrrrrrrrrr}
\hline NEGARA & $\mathbf{1 9 9 5}$ & $\mathbf{1 9 9 6}$ & $\mathbf{1 9 9 7}$ & $\mathbf{1 9 9 8}$ & $\mathbf{1 9 9 9}$ & $\mathbf{2 0 0 0}$ & $\mathbf{2 0 0 1}$ & $\mathbf{2 0 0 2}$ & $\mathbf{2 0 0 3}$ & $\mathbf{2 0 0 4}$ & $\mathbf{2 0 0 5}$ \\
\hline Cina & $\mathbf{0}$ & $\mathbf{0}$ & $\mathbf{0}$ & $\mathbf{0}$ & $\mathbf{0}$ & $\mathbf{0}$ & $\mathbf{0}$ & $\mathbf{0}$ & $\mathbf{2 0 1} \mathbf{7 4 0}$ & $\mathbf{2 1 6} \mathbf{9 5 9}$ & $\mathbf{2 4 5} \mathbf{3 2 9}$ \\
Flipina & $\mathbf{1 8} \mathbf{0 3 1}$ & $\mathbf{1 4 . 3 7 5}$ & $\mathbf{2 2 . 4 3 0}$ & $\mathbf{1 6} \mathbf{9 6 8}$ & $\mathbf{2 3} \mathbf{7 8 2}$ & $\mathbf{2 1} \mathbf{2 7 0}$ & $\mathbf{1 6} \mathbf{7 1 3}$ & $\mathbf{1 9} \mathbf{6 4 2}$ & $\mathbf{1 9 3 7 4}$ & $\mathbf{2 8} \mathbf{3 7 5}$ & $\mathbf{3 0} \mathbf{7 7 5}$ \\
Indonesia & 3240 & 2343 & 8282 & 1559 & 9257 & 9227 & 6982 & 4831 & 2014 & 3948 & 9108 \\
Taiwan & 15530 & 8538 & 4464 & 8274 & 4157 & 3235 & 4090 & 1880 & 2109 & 2159 & 1907 \\
Malaysia & 1389 & 1673 & 1184 & 1262 & 601 & 743 & 971 & 886 & 795 & 679 & 463 \\
Thailand & 91 & 394 & 308 & 43 & 28 & 27 & 19 & 40 & 41 & 92 & 85 \\
\hline
\end{tabular}

Sumber: FAO-FIGIS dalam Shelley (2008).

\section{PENGELOLAAN MEDIA AIR LAUT}

Air laut sebagai media hidup kepiting bakau memiliki peranan penting dalam menunjang kehidupan dan pertumbuhan. Pada proses pembenihan kepiting, stadium larva sangat rentan terhadap kondisi kualitas air laut, sehingga sangat diperlukan pengelolaan kualitas air laut agar air laut yang digunakan untuk pemeliharaan selalu dalam kondisi yang ideal. Menurut Blackshaw (2001), air laut yang telah disimpan lebih dari tiga minggu yang disebut mature sea water secara mikrobiologi baik untuk budidaya. Tetapi dengan menggunakan metode ini, fasilitas penampungan air laut harus besar dan kapasitas pemeliharaan menjadi terbatas. Namun Juwana (1995) telah berhasil menggunakan fresh sea water sebanyak 10.000 L/hari untuk produksi benih rajungan (Portunus pelagicus). Tentu saja air laut tersebut harus melalui serangkaian perlakuan seperti: klorinasi, deklorinasi, filterisasi dan sterilisasi dengan lampu ultra violet.

Metode penyediaan air laut/air tawar bebas kuman yang digunakan Juwana (2006), diperoleh melalui serangkaian proses yaitu sebagai berikut: 
1. Filterisasi mengggunakan media katrid berukuran $5 \mu$ dan $1 \mu$ yang dirangkai secara parallel;

2. Klorinasi dengan klorin cair dalam kadar tertentu; kemudian,

3. Klorin yang terlarut dalam air akan menguap. Proses penguapan klorin ini disebut deklorinasi. Deklorinasi dapat dipercepat dengan pengadukan air (resirkulasi) maupun pengudaraan (aerasi). Namun, uap klorin berbahaya bagi para pelaksana budidaya, karena dapat terhisap paru-paru dan masuk ke dalam sirkulasi darah manusia yang dapat mengakibatkan berbagai penyakit. Untuk menghindari hal tersebut, uap klorin dialirkan ke udara terbuka di luar ruangan menggunakan exhaust fan;

4. Radiasi lampu ultra violet. Air laut yang telah dideklorinasi, kemudian dialirkan ke bak-bak tandon yang dilengkapi dengan sistem radiasi lampu ultra violet (germicidal lamp) untuk membasmi semua kuman yang bertahan.

\section{PENYEDIAAN INDUK KEPITING MEMIJAH DI LABORATORIUM}

Induk kepiting yang dapat digunakan untuk pembenihan adalah kepiting betina dewasa yang telah matang gonad atau yang telah memijah di alam. Menggunakan induk kepiting yang telah memijah di alam untuk pembenihan, akan menghemat proses atau waktu yang dibutuhkan. Hal ini dikarenakan pembuahan telur telah terjadi, tinggal menunggu telur menetas. Sedangkan dengan menggunakan induk kepiting betina matang gonad diperlukan proses pemeliharaan induk untuk pemijahan di lingkungan buatan, sehingga waktu yang dibutuhkan lebih panjang.

Kepiting betina dewasa yang telah memijah jarang ditemukan atau tertangkap oleh nelayan kepiting, hal ini berkaitan dengan karakter alamiahnya yang bermigrasi ke lepas pantai setelah memijah untuk menetaskan telur-telurnya (Arriola, 1940; Ong, 1966; Hill, 1975). Oleh karena itu, induk kepiting yang digunakan untuk pembenihan merupakan kepiting dewasa matang gonad yang diperoleh dari alam dan dipelihara di hatchery atau laboratorium sampai memijah (Juwana \& Permadi, 2014; Pratama et al., 2016).

Menurut Subagio (2002), kualitas pakan berpengaruh nyata terhadap fekunditas ovarium. Sehingga induk kepiting matang gonad yang dipelihara untuk pembenihan memerlukan pakan yang berkualitas guna keberhasilan produksi benih. Oleh karena itu, kualitas pakan merupakan topik penelitian yang menunjang keberhasilan suatu usaha pembenihan kepiting.

\section{PENGARUH WARNA BAK BUDIDAYA TERHADAP PERKEMBANGAN BURAYAK KEPITING}

Beberapa penelitian terhadap warna bak budidaya yang digunakan dalam proses pembenihan kepiting, menunjukan pengaruh terhadap kelangsungan 
hidup benih. Oleh karena itu, perlu diketahui warna bak yang sesuai untuk pemeliharaan benih kepiting tersebut. Rusdi (2005) melaporkan bahwa warna bak pemeliharaan Zoea kepiting bakau Scylla paramamosain mempengaruhi kelangsungan hidup megalopa yaitu: 3,5\% (warna bak hitam dengan dasar putih) $0,2 \%$ (warna bak biru dasar putih) dan $0,1 \%$ (seluruh bak warna putih). Rabbani et al. (2005) juga melaporkan bahwa bak pemeliharaan larva kepiting Scylla serrata yang berwarna gelap memberikan sintasan yang lebih tinggi dibandingkan dengan bak warna terang. Mereka telah memelihara larva kepiting dalam lima bak dengan warna hitam, hijau tua, merah tua, biru langit dan putih. Larva yang dipelihara di bak dengan warna gelap mempunyai waktu lebih pendek dan lebih ada sinkronisasi dalam perkembangannya.

\section{PENETAPAN KRITERIA OPTIMUM UNTUK PEMBENIHAN DAN PEMBESARAN KEPITING}

Kondisi dan kualitas air laut yang digunakan untuk pembenihan kepiting bakau sangat berpengaruh terhadap kelulushidupan dan pertumbuhan benih, sehingga informasi mengenai kriteria optimum air laut sebagai media dalam pembenihan sangat diperlukan. Keenan et al. (1998) menetapkan empat spesies Scylla di perairan IndoPasifik dan menjumpai bahwa setiap species Scylla mempunyai habitat yang berbeda, sehingga ada kemungkinan salinitas optimum untuk pemeliharaan larva kepiting berbeda antar spesies.
Balai Besar Riset Perikanan Budidaya Laut (2002) melaporkan bahwa salinitas terbaik untuk pemeliharaan burayak (Krablet) Scylla paramamosain adalah $27 \mathrm{ppt}(36 \%)$ disusul salinitas $31 \mathrm{ppt}$ (13,3\%), 23 ppt (9,33\%), 35 ppt (4\%) dan 19 ppt (1,33\%). Kemudian Rusdi \& Karim (2006) menyatakan bahwa salinitas (4, $10,16,22,28,34 \mathrm{ppt}$ ) tidak berpengaruh terhadap kelulushidupan burayak Scylla paramamosain tetapi nyata berpengaruh terhadap pertumbuhan berat tubuh dan salinitas 16 ppt memberikan laju pertumbuhan dan pertumbuhan berat tubuh kepiting terbaik dibandingkan dengan salinitas lain yang diujikan. Selanjutnya Rusdi \& Hanafi (2002) melaporkan bahwa sintasan krablet Scylla paramamosain asal hatchery setelah 80 hari mencapai $42,73 \%$ di perairan mangrove dengan suhu berkisar $28-33{ }^{\circ} \mathrm{C}$ dan salinitas berkisar 29-5 ppt, dengan laju pertumbuhan harian lebar karapas rata-rata $1,77 \%$ dan laju pertumbuhan harian berat tubuh 2,20\%. Karim (2007) menyatakan bahwa pemangsaan dan konsumsi oksigen tertinggi kepiting Scylla serrata terjadi pada salinitas 25 ppt dan terendah pada salinitas 5 ppt.

\section{PRODUKSI BENIH KEPITING BAKAU Scylla serrata}

Usaha pemeliharaan burayak kepiting bakau untuk penelitian produksi benih kepiting telah dilaporkan oleh beberapa penulis. Penelitian Quinitio et al. (2001) terhadap pemeliharaan zoea Scylla serrata memperoleh sintasan megalopa sebesar 0,15 - 0,74\%. Kemudian dari megalopa ke crab instar umur 31 hari 
memperoleh sintasan $1-10 \%$. Kalau dihitung dari saat zoea menetas sampai dengan crab umur 9 hari memperoleh sintasan $0,155 \%$ (Tabel 4). Hasil penelitian lain yang dilakukan oleh Yi et al. (2009) memperoleh sintasan 0,25\% untuk produksi benih Scylla serrata stadium crab III (Tabel 5). Keberhasilan peningkatan sintasan benih kepiting yang diperoleh Yi et al. (2009) disebabkan pemberian rumpon (plastic shade films or net pens) pada akhir zoea 5 (Tabel 5) untuk mencegah terjadinya kanibalisme, karena pada stadium tersebut capit mulai terbentuk.

Tabel 4. Produksi benih kepiting Scylla serrata (Quinitio et al. 2001).

\begin{tabular}{|c|c|}
\hline Salinitas (psu) & $32-34$ \\
\hline Suhu $\left({ }^{\circ} \mathrm{C}\right)$ & $26-30,5$ \\
\hline Periode penerangan & 12 jam terang : 12 jam gelap \\
\hline Waktu Pemijahan terjadi & Tidak disebutkan; stok induk diperoleh setiap 4 bulan. \\
\hline Periode Inkubasi & $9,10,11$ \\
\hline Jumlah Larva yang menetas & $1100,1550,1955,2700 \times(1000)$ \\
\hline $\begin{array}{l}\text { Kepadatan awal } \\
\text { pemeliharaan larva }\end{array}$ & $\begin{array}{l}\text { Zoeae dipelihara dalam tangki melingkar berkapasitas } 1,5 \text { dan } \\
10^{3} \text { dengan padat penebaran } 30 \text { hingga } 50 \text { individu/L }\end{array}$ \\
\hline Pakan untuk larva & $\begin{array}{l}\text { Brachionus rotundiformis diberikan sebanyak } 10 \text { sampai } \\
15 \text { individu/mL pada Zoea } 1 \text {-Zoea } 2 . \\
\text { Nauplii Artemia salina diberikan sebanyak 1-3individu/ } \\
\text { mL pada Zoea } 3 \\
\circ \quad \text { Meningkat menjadi } 5 \text { individu/mL saat Megalopa. }\end{array}$ \\
\hline Pergantian air & $\begin{array}{l}\text { Mulai pada hari ke } 3 \text { sekitar } 30 \% \text { air diganti setiap hari dan } \\
\text { meningkat menjadi 50\% seiring perkembangan larva }\end{array}$ \\
\hline $\begin{array}{l}\text { Upaya untuk mencegah } \\
\text { kanibalisme }\end{array}$ & $\begin{array}{l}\text { Megalopa ditebar dengan kepadatan } 1.000 \text { individu/m3 } \\
\text { Makanan terdiri dari } 3 \text { hingga } 5 \text { individu / mL nauplii Artemia } \\
\text {, dan beralih ke ikan rucah, kerang hijau, atau udang rebon } \\
\text { diberikan sesuai kebutuhan dua kali setiap hari segera setelah } \\
\text { Megalopa bermetamorfosis menjadi kepiting. }\end{array}$ \\
\hline \multicolumn{2}{|c|}{ Tingkat Kelangsungan Hidup dan Durasi Pertumbuhan larva Scylla serrata } \\
\hline Stadia & Kelangsungan Hidup \\
\hline \multicolumn{2}{|l|}{ Zoea -1} \\
\hline \multicolumn{2}{|l|}{ Zoea -2} \\
\hline \multicolumn{2}{|l|}{ Zoea -3} \\
\hline \multicolumn{2}{|l|}{ Zoea -4} \\
\hline \multicolumn{2}{|l|}{ Zoea -5} \\
\hline Megalopa & Zoea ke Megalopa : $0.15 ; 0.6 ; 0.67$; dan $0.74 \%$ \\
\hline Crablet & $\begin{array}{l}\text { Megalopa ke Crab :1 - } 10 \%(\mathrm{C} 31) ; 30 \% \text { (C16); dan } 21 \% \\
\text { (C9=9 hari menjadi Crab). }\end{array}$ \\
\hline
\end{tabular}


Tabel 5. Produksi benih kepiting Scylla serrata (Yi et al. 2009).

\begin{tabular}{|c|c|c|c|c|c|}
\hline \multicolumn{2}{|l|}{ Salinitas (psu) } & \multicolumn{4}{|l|}{34} \\
\hline \multicolumn{2}{|l|}{ Suhu $\left({ }^{\circ} \mathrm{C}\right)$} & \multicolumn{4}{|l|}{30} \\
\hline \multicolumn{2}{|c|}{ Waktu pemijahan } & \multicolumn{4}{|c|}{$\begin{array}{l}\text { 20, 23, 28, } 36 \text { hari setelah ablasi (pemotongan tangkai mata) } \\
\text { atau } 23 \text { hingga } 52 \text { hari tanpa ablasi }\end{array}$} \\
\hline \multicolumn{2}{|c|}{ Periode inkubasi } & \multicolumn{4}{|c|}{$9,10,11$ hari } \\
\hline \multicolumn{2}{|c|}{ Jumlah larva yang menetas } & \multicolumn{4}{|c|}{$2,4-2,5$ juta } \\
\hline \multicolumn{2}{|c|}{$\begin{array}{l}\text { Pemberian pakan larva } 4 \\
\text { kali sehari }\end{array}$} & \multicolumn{4}{|c|}{$\begin{array}{l}\text { Larva Zoea } 1 \text { - Zoea } 5 \text { diberi makan rotifera yang diperkaya } \\
\text { DHA dengan kepadatan } 25 \text { individu / mL. } \\
\text { Pakan udang komersial mulai ditambahkan saat Zoea } 2 \\
\text { Nauplii Artemia yang telah diperkaya DHA diberikan 2-3 } \\
\text { individu/mL pada Zoea } 3 .\end{array}$} \\
\hline \multicolumn{2}{|c|}{ Pergantian air } & \multicolumn{4}{|c|}{$10 \%$ sekali sehari, pada pagi hari. } \\
\hline \multicolumn{2}{|c|}{$\begin{array}{l}\text { Usaha untuk mencegah } \\
\text { kanibalisme }\end{array}$} & \multicolumn{4}{|c|}{$\begin{array}{l}\text { Pada akhir tahap Zoea 5, naungan plastik penempel dan 0,5 } \\
\mathrm{mm} \\
\text { kurungan jaring }(30 \times 50 \mathrm{~cm}) \text { ditempatkan di wadah } \\
\text { pemeliharaan }\end{array}$} \\
\hline \multicolumn{6}{|c|}{ Tingkat Kelangsungan Hidup dan Durasi Pertumbuhan Larva Scylla serrata. } \\
\hline Stadia & \multicolumn{2}{|c|}{ Ukuran (mm) } & Usia (day) & Kematian (\%) & $\begin{array}{c}\text { Kelangsungan } \\
\text { hidup (\%) }\end{array}$ \\
\hline Zoea -1 & \multicolumn{2}{|c|}{$\begin{array}{l}1.33 \text { (panjang } \\
\text { tubuh) }\end{array}$} & 2 & 90 & \\
\hline Zoea -2 & \multicolumn{2}{|c|}{1.63} & 4 & 80 & \\
\hline Zoea -3 & \multicolumn{2}{|l|}{2.09} & 6 & 50 & \\
\hline Zoea -4 & \multicolumn{2}{|l|}{3.05} & 9 & 50 & \\
\hline Zoea -5 & \multicolumn{2}{|l|}{4.06} & 12 & 50 & \\
\hline Megalopa & \multicolumn{2}{|c|}{$\begin{array}{c}1.79 \text { (lebar } \\
\text { karapas) }\end{array}$} & 15 & 50 & \\
\hline Crab -1 & \multicolumn{2}{|c|}{3.06} & 22 & 50 & \\
\hline Crab -2 & \multicolumn{2}{|l|}{5.02} & 26 & 50 & \\
\hline Crab -3 & \multicolumn{2}{|l|}{5.80} & 29 & 50 & $\begin{array}{l}0.25 \quad(2,500 \\
\text { Juvenil })\end{array}$ \\
\hline
\end{tabular}

PRODUKSI BENIH KEPITING

BAKAU Scylla paramamosain

Produksi benih kepiting bakau spesies Scylla paramamosain juga telah dilaporkan oleh Balai Besar Riset Perikanan Budidaya Laut (2002), sebanyak tiga kali percobaan pemeliharaan burayak. Hasil Percobaan
I menunjukkan sintasan zoea 5 dengan inokulasi bakteri probiotik K-7 memperoleh nilai yang paling tinggi dibandingkan dengan kontrol dan perlakuan lainnya. Percobaan II menunjukkan salinitas $27 \mathrm{pptmemberikan}$ sintasan zoea paling tinggi pada hari ke-8 dibanding salinitas lain yang diujikan 
(19 ppt, 23 ppt, 31 ppt dan 35 ppt). Percobaan III memperoleh hasil sintasan sekitar 0,8\% (Tabel 6). Peningkatan produksi kepiting diperoleh Susanto et al. (2006) dan Nghia et al. (2007) dengan kombinasi teknik pemeliharaan dengan teknik memperkaya pakan hidup, sehingga berhasil memperoleh kelulushidupan zoea 1 sampai dengan crab
1-2 sebanyak 10-15\%. Keberhasilan tersebut dicapai dengan teknik budidaya yang menggunakan green water (Tabel 7 dan Tabel 8). Hal ini tidak dapat diterapkan untuk hatchery yang tidak membudidayakan fitoplankton karena area budidaya, bak-bak budidaya, dan tandon air laut terbatas.

Tabel 6. Produksi benih kepiting Scylla paramamosain (BBRPBL 2002).

\begin{tabular}{|c|c|c|c|}
\hline \multicolumn{3}{|l|}{ Salinitas (psu) } & \multicolumn{3}{l|}{ Terbaik 27 ppt (diantara 19, 23, 27, 31 dan 35 ppt) } \\
\hline Suhu $\left({ }^{\circ} \mathrm{C}\right)$ & 29 & Umur (day) & Kelangsungan Hidup \\
\hline \multicolumn{3}{|l|}{ Kelangsungan hidup dan waktu yang dibutuhkan untuk perkembangan larva S. paramamosain } \\
\hline Stadia & Ukuran (mm) & $\begin{array}{c}50 \text { x } 4000 \text { Zoea I (kepadatan } \\
\text { awal) }\end{array}$ \\
\hline Zoea -1 & & & \\
\hline Zoea -2 to Z -5 & & 14 & \\
\hline Megalopa & & 21 & $0,8165 \%$ (1.633 juvenil) \\
\hline Crab -1 & & 26 & \\
\hline Crab -2 & & &
\end{tabular}

Tabel 7. Kelulus-hidupan larva kepiting S. paramamosain (Susanto et al. 2006).

\begin{tabular}{|l|l|l|l|}
\hline & Kepadatan & Volume 3.000 L & $\begin{array}{c}\text { Kelangsungan } \\
\text { hidup }\end{array}$ \\
\hline Padat penebaran awal Zoea I & $100 \mathrm{Z} / \mathrm{L}$ & $\begin{array}{l}100 \times 3.000=300.000 \\
\text { Zoea I }\end{array}$ & $100 \%$ \\
\hline Kepadatan Megalopa (12 hari) & $20 \mathrm{M} / \mathrm{L}$ & $60.000 \mathrm{Megalopa}$ & $19,23 \%$ \\
\hline Produksi benih CrabI (16 hari) & $15 \mathrm{C} / \mathrm{L}$ & 15.000 Crab I & $14,71 \%$ \\
\hline Produksi Crab IV (26 hari) & $6 \mathrm{C} 4 / \mathrm{L}$ & 6.000 Crab IV & $5,46 \%$ \\
\hline
\end{tabular}

Tabel 8. Produksi benih kepiting Scylla paramamosain oleh Nghia et al. (2007).

\begin{tabular}{|c|c|c|c|}
\hline Acuan & \multicolumn{3}{|c|}{ Nghia et al. (2007) } \\
\hline Jenis & \multicolumn{3}{|c|}{ Scylla paramamosain } \\
\hline \multicolumn{4}{|c|}{ Salinitas (psu) } \\
\hline Suhu $\left({ }^{\circ} \mathrm{C}\right)$ & \multicolumn{2}{|l|}{29} & \\
\hline \multicolumn{4}{|c|}{$\begin{array}{l}\text { Kelangsungan hidup dan waktu yang dibutuhkan untuk perkembangan larva } S \text {. } \\
\text { paramamosain }\end{array}$} \\
\hline Stadia & Ukuran (mm) & Umur (day) & Kelangsungan Hidup (\%) \\
\hline \multicolumn{4}{|l|}{ Zoea -1 to -5} \\
\hline \multicolumn{4}{|l|}{ Megalopa } \\
\hline \multicolumn{4}{|l|}{ Crab - 1} \\
\hline Crab -2 & & & $10-15 \%$ (maksimum $30 \%$ ) \\
\hline
\end{tabular}




\section{PRODUKSI BENIH KEPITING} Scylla tranquebarica

Penelitian pembenihan kepiting Scylla tranquebarica telah dilaporkan oleh Thirunavukkarasu et al. (2014). Uraian hasil penelitian yang dilakukan Thirunavukkarasu et al. (2014) sebagai berikut: induk kepiting dan larva zoea I sampai zoea $\mathrm{V}$ dipelihara pada salinitas 35 ppt dan menjelang stadium megalopa, salinitas diturunkan menjadi 26 ppt. Pakan yang diberikan pada zoea I berupa Brachionus rotundiformis, kemudian setelah memasuki zoea II sampai zoea IV diberi pakan Brachionus rotundiformis dan nauplii Artemia, sedangkan memasuki zoea $\mathrm{V}$ pakan yang diberikan berupa nauplii Artemia dan diet formulasi. Hasil sintasan crab I 6,9 $\%$ dengan durasi pemeliharaan selama 22 hari. Upaya yang dilakukan untuk mengatasi kanibalisme pada penelitian ini dilakukan dengan memasang shelter pada saat stadium megalopa. Hasil penelitian Thirunavukkarasu et al. (2014) lebih lanjut disajikan pada tabel 9.

Tabel 9. Produksi benih kepiting Scylla tranquebarica (Thirunavukkarasu et al., 2014).

\begin{tabular}{|c|c|}
\hline Salinitas (psu) & $\begin{array}{l}35 \text { ppt pada saat pemeliharaan induk sampai larva zoea V dan } \\
\text { diturunkan menjadi } 26 \mathrm{ppt} \text { menjelang stadium megalopa }\end{array}$ \\
\hline Suhu $\left({ }^{\circ} \mathrm{C}\right)$ & $30-32,5$ \\
\hline Periode penerangan & Tidak disebutkan \\
\hline Waktu Pemijahan terjadi & $\begin{array}{l}\text { Stok induk diperoleh dari hasil penangkapan dengan trawl } \\
\text { dalam kondisi telah memijah. }\end{array}$ \\
\hline Periode Inkubasi & 12 hari \\
\hline $\begin{array}{l}\text { Jumlah Larva yang } \\
\text { menetas }\end{array}$ & tidak disebutkan \\
\hline $\begin{array}{l}\text { Kepadatan awal } \\
\text { pemeliharaan larva }\end{array}$ & 50 individu/L \\
\hline Pakan untuk larva & $\begin{array}{l}\text { Brachionus rotundiformis diberikan pada zoea I, zoea II-zoea } \\
\text { IV diberikan pakan rotifer dengan dominasi nauplii Artemia, } \\
\text { zoea V-megalopa diberikan pakan nauplii Artemia dengan } \\
\text { dominasi diet formulasi (pakan buatan). Pakan diberikan dua } \\
\text { kali sehari pada pagi dan sore hari secara adlibitum. }\end{array}$ \\
\hline Pergantian air & Mulai pada hari ke 5 sekitar 20\% air diganti setiap hari. \\
\hline $\begin{array}{l}\text { Upaya untuk mencegah } \\
\text { kanibalisme }\end{array}$ & $\begin{array}{l}\text { Megalopa ditebar dengan kepadatan } 2 \text { individu/L } \\
\text { Memasang shelter berupa jaring dan pipa pvc ke dalam wadah } \\
\text { pemeliharaan menjelang larva bermetamofosis menjadi } \\
\text { megalopa. }\end{array}$ \\
\hline
\end{tabular}




\begin{tabular}{|c|c|}
\hline \multicolumn{2}{|c|}{ Tingkat Kelangsungan Hidup dan Durasi Pertumbuhan larva Scylla tranquebarica } \\
\hline Stadia & Kelangsungan Hidup (\%) \\
\hline Zoea -1 & 62,7 \\
\hline Zoea -2 & 44,8 \\
\hline Zoea -3 & 33,1 \\
\hline Zoea -4 & 20,6 \\
\hline Zoea -5 & 12,5 \\
\hline Megalopa & 6,9 \\
\hline Crablet & Tidak disebutkan \\
\hline
\end{tabular}

\section{PENYEDIAAN PAKAN HIDUP UNTUK BURAYAK KEPITING}

Pembenihan kepiting secara umum menggunakan ransum makanan berupa nauplii Artemia dan rotifera. Rotifera adalah zooplankton yang dibudidayakan dengan fitoplankton. Hal ini menyebabkan perjalanan yang panjang dalam kegiatan pembenihan kepiting, sehingga terjadi kemungkinan pakan hidup (rotifer) menjadi transmitter penyakit (Yan et al., 2007). Disamping itu, penggunaan strain fitoplankton untuk mengembangkan rotifer juga harus dipilih, selain baik untuk pertumbuhan rotifer juga menunjang kehidupan larva krustasea (Sayegh et al., 2007). Produksi benih kepiting yang tidak berhasil terutama disebabkan oleh penyakit yang berkembang pada saat pemeliharaan larva. Informasi mengenai naulpii Artemia dan rotifer (Brachionus spp.) sebagai pakan hidup larva kepiting diulas lebih lanjut pada urian berikut ini.

\section{Nauplii Artemia}

Telur Artemia kering merupakan produk yang mudah dipasarkan dalam kemasan kaleng atau aluminium foil. Telur Artemia kemasan akan menetas menjadi nauplii Artemia apabila dimasukkan ke dalam air laut. Nauplii Artemia merupakan pakan hidup yang sesuai untuk memelihara larva biota laut. Cairan kaporit-soda merupakan cairan dekapsulasi yang dapat mengkikis cangkang telur Artemia, selain itu, penggunaan cairan dekapsulasi juga akan menghilangkan kotoran dan kontaminan yang melekat di kulit telur, sehingga telur Artemia mudah menetas tanpa kontaminan. Kondisi air laut yang baik untuk dekapsulasi telur Artemia adalah salinitas 30 ppt, suhu ruang, dan diaerasi, sehingga telur dapat menetas dalam waktu 15 jam (Juwana, 1993).

Zoea kepiting dapat memangsa nauplii Artemia yang baru menetas. Namun nauplii Artemia berkembang cepat, dalam waktu beberapa jam ukurannya akan terlalu besar untuk bukaan mulut zoea kepiting, sehingga pemberian nauplii Artemia tidak dapat diberikan sekaligus (sekali/hari). Untuk menyediakan nauplii Artemia yang berukuran kecil dapat dilakukan penetasan beberapa kali dalam sehari, tanpa harus melakukan dekapsulasi telur Artemia berulang-ulang, karena telur yang telah didekapsulasi dapat disimpan 
kembali di lemari es, kemudian ditetaskan pada saat diperlukan (Juwana, 2006). Mann et al. (2001) telah mencoba nauplii Artemia dari delapan macam produk, namun hanya dua produk yang berhasil menyebabkan metamorphosis I dari zoea ke megalopa Scylla serrata. Oleh karena itu, pengkayaan nilai nutrisi nauplii Artemia diperlukan untuk menjamin kesuksesan pembenihan kepiting.

\section{Rotifera (Brachionus spp.)}

Rotifera adalah zooplankton yang dikembangkan dengan fitoplankton. Rotifera berfungsi sebagai amplop yang berisi unsur-unsur fitoplankton yang diperlukan oleh burayak kepiting (Kasry, 1986). Dalam hal ini, rotifera mempunyai enzim yang dapat mencerna fitoplankton, sehingga nilai nutrisinya dapat diserap oleh burayak kepiting. Resiko dalam penggunaan rotifera tersebut adalah dapat berfungsi sebagai pembawa penyakit (Yan et al., 2007).

Dalam aktivitas pembenihan kepiting, pemeliharaan stadium zoea awal kepiting (zoea 1 dan zoea 2) pada umumnya menggunakan rotifera (Brachionus spp) (Brick, 1974; Heasman \& Fielder, 1983; Mardjono \& Arifin, 1993; Cowan, 1984; Wahyuni, 1985; Kasry, 1986; Juwana \& Suprapto, 1992; Quinitio et al., 2001; Balai Besar Riset Perikanan Budidaya Laut, 2002; Yi et al., 2009; Nghia et al., 2007; Thirunavukkarasu et al., 2014.). Menurut Yatsuzuka (1962) yang telah memelihara delapan spesies kepiting Brachyura, berdasarkan jenis pakannya dapat dikelompokkan menjadi dua kelompok, yaitu kelompok karnivorous yang hanya memangsa hewan saja: Neptunus pelagicus, $N$. trituberculatus, Charybdis japonicas; dan kelompok Polyphagous yang memangsa baik hewan maupun tumbuhan: Eriocheir japonicas, Sesarma haematocheir, S. dehaani, Scopimera globosa, Philyra piston. Jenis pakan berupa fitoplankton antara lain Skeletonema costatum, Ditylum sol, dan Thalassiosira sp., sedangkan jenis pakan hewani disamping rotifera dapat digunakan nauplius Balanus Amphitrite albicostatus, stadium awal oyster Ostrea gigas.

\section{PENYEDIAAN PAKAN BUATAN UNTUK PEMBENIHAN DAN PENDEDERAN KEPITING}

Upaya yang dilakukan untuk menunjang pertumbuhan larva dan juvenil kepiting (krablet) dapat dilakukan dengan pemberian pakan hidup maupun pakan buatan (diet formulasi). Beragam bahan digunakan untuk menghasilkan diet formulasi yang dapat mendukung sintasan dan pertumbuhan larva maupun juvenil. Penggunaan diet formulasi berupa tepung kering sebagai pakan tambahan disamping pakan hidup (Rotifera dan nauplii Artemia) untuk pemeliharaan zoea kepiting telah dilakukan oleh beberapa penulis (Balai Besar Riset Perikanan Budidaya Laut, 2002; Nghia et al., 2007). Pakan buatan untuk pendederan kepiting Scylla serrata menggunakan bahan utama berupa ikan, udang, moluska dengan kadar protein 50$51 \%$. Tambahan unsur berupa lipid dapat diperoleh dari sumber nabati maupun hewani (corn oil, soy bean oil, cod liver 
oil). Lecithin merupakan kandungan yang harus ada di dalam pakan, dan kandungan ini dapat diperoleh dari tepung kedelai. Sebagai perekat dapat digunakan tepung terigu, tepung jagung dan telur (Holme et al., 2006; Trino et al., 2001; Juwana, 2006). Disamping itu, Vu-Anh et al. (2006) menyatakan bahwa krablet dapat mencerna sellulose. Oleh karena itu, sellulose dapat dipertimbangkan sebagai bahan pakan yang murah, sehingga dapat mengurangi penggunaan bahan hewani. Menurut Ponat \& Adelung (1998), kepiting memakan rumput laut karena memerlukan bahan-bahan yang terkandung didalamnya, seperti karoten yang tidak dapat disintesa dalam tubuh. Giri et al. (2002) melaporkan bahwa kebutuhan protein optimum untuk menghasilkan pertumbuhan maksimum yuwana (juvenil) kepiting bakau adalah $47,6 \%$.

\section{PENUTUP}

Metodemaupunteknikpembenihan kepiting bakau sampai saat ini masih dalam skala penelitian ataupun percobaan dengan tingkat kelangsungan hidup benih yang dihasilkan rendah, sehingga belum dapat diaplikasikan dalam skala industri. Dari paparan diatas dapat disimpulkan bahwa aspek yang belum banyak diteliti yaitu : (1) peningkatan kualitas induk dan (2) penanggulangan penyakit.

Saat ini, induk kepiting yang digunakan dalam produksi benih umumnya merupakan kepiting betina dewasa yang telah matang gonad ataupun telah memijah di alam. Induk kepiting yang memiliki gen unggul merupakan faktor pendukung penting dalam meningkatkan produksi benih. Sampai saat ini belum ada informasi terkait upaya untuk menghasilkan induk kepiting berkualitas atau yang lebih dikenal pemuliaan induk. Kemudian, tingkat kematian masal yang terjadi selama proses pembenihan sangat dimungkinkan disebabkan oleh penyakit. Namun, informasi terkait penyakit yang timbul selama proses pembenihan kepiting belum banyak diteliti. Oleh karena itu, saat ini dan kedepannya upaya yang perlu dilakukan untuk meningkatkan produksi benih kepiting bakau adalah menghasilkan induk kepiting bakau yang memiliki gen unggul, serta penanganan penyakit yang muncul dalam pembenihan dengan pendekatan bioteknologi.

\section{DAFTAR PUSTAKA}

Agbayani, R.F., D.D. Baliao, G.P.B. Samonpe and R.E. Tumaliuan. 1990. Economic feasibility analysis of the monoculture of mud crab (Scylla serrata) FORSKAL. Aquaculture 91: $223-231$.

Arriola, F.J. 1940. A preliminary study of the life history of Scylla serrata (Forskal). Philipp. J. Science 73: 437-456.

Balai Besar Riset Perikanan Budidaya Laut. 2002. Pengembangan sentra-sentra andalan untuk budidaya kepiting bakau di Indonesia dan Vietnam. dalam : I Soesilo (eds.) Australia- 
Indonesia Fisheries Showcase. 20 years of collaborative research, Jakarta, 31 Juli 2002 Badan Riset Kelautan dan Perikanan bekerjasama dengan The Australian Center for International Agricultural Research: $1 \mathrm{hlm}$.

Blackshaw. 2001. Larval culture of Scylla serrata: Maintenance of hygiene and concepts of experimental design. Asian Fisheries Science 14: 239-242.

Brick, R.W. 1974. Effects of water quality, antibiotics, phytoplankton and food on survival and development of larvae of Scylla serrata. Aquaculture 3: 231 244.

Cholik, F. and A. Hanafi. 1992. A review of the status of the mud crab (Scylla sp.) fishery and culture in Indonesia. dalam : ASFA 1 (23) 6: 11739 - IQ23.

Cowan, L. 1984. Crab farming in japan, Taiwan and the Philippines. Queensland Department of Primary Industries, Brisbane, Qld. Australia Information series Q 184009 : 43-61.

Giri, N.A., Yunus, K. Suwirya dan M. Marzuqi. 2002. Kebutuhan protein untuk pertumbuhan yuwana kepiting bakau, Scylla paramamosain. Jurnal Penelitian Perikanan Indonesia 8 (5): 31-36.
Gunarto dan Ibnu Rusdi. 1993. Budidaya kepiting bakau Scylla serrata di tambak pada padat penebaran berbeda. Jurnal Penelitian Budidaya Pantai 9 (3): 7 - 19.

Heasman, M.P. and D.R. Fielder. 1983. Laboratory spawning and mass rearing of the mangrove crab Scylla serrata (Forskal), from first zoea to first crab stage. Aquaculture 34: 303 - 316.

Hill, B.J. 1974. Salinity and temperature tolerance of zoea of the portunid crab Scylla serrata. Marine Biology 25: 21 - 24.

Hill, B.J. 1975. Abundance, breeding and growth of the crab Scylla serrata in two South African Estuaries. Marine Biology 32 : 119-126.

Holme, M.H., C. Zeng and P.C. Southgate. 2006. The effects of supplemental dietary cholesterol on growth, development and survival of mud crab, Scylla serrata, megalopa fed semi-purified diets. Aquaculture 261 : 13281334.

Juwana, S. and D. Suprapto. 1992. The effects of feeding regimes, environmental condition and initial densities of larvae on survival and development of Scylla serrata larvae reared in the laboratory. In : T. Sugimoto, K. Romimohtarto, S. Soemodihardjo, H. Nakata 
(Eds.) Proceedings of Third ORI-LIPI Seminar on Southeast Asia Marine Science : Oceanography for Fisheries. Sponsored by JSPS, Tokyo, August 1992 : $128-136$.

Juwana, S. 1993. Laporan Kemajuan Penelitian Tahap III Budidaya Kepiting (Scylla serrata) dan rajungan (Portunus pelagicus), 1 Oktober 1992 10 April 1993. Dalam Rangka Kerjasama UNDIP dengan Puslitbang Oseanologi - LIPI.

Juwana, S. 1995. Produksi massal benih rajungan (Portunus pelagicus) di Pusat Penelitian dan Pengembangan Oseanologi LIPI, Jakarta: I. Peningkatan produksi benih rajungan siap tebar. Dalam: A. Soegiarto et al. (Eds.) Prosiding Kongres Ilmu Pengetahuan Nasional (KIPNAS) VI. PUSPIPTEK Serpong, 12-16 September 1995. Buku III: 129-145.

Juwana, S. 2006. Petunjuk Praktis Pembenihan Rajungan (Portunus pelagicus) di Pusat Penelitian Oseanografi LIPI, Jakarta. Pusat Penelitian Oseanografi Lembaga Ilmu Pengetahuan Indonesia, Jakarta : $45 \mathrm{hlm}$.

Juwana, S., Ruyitno, Soewartoyo, L.I. Sutiknowati, Asngadi, Sujono dan I.S. Safari. 2007. Alih teknologi pembenihan rajungan, meningkatkan perikanan rajungan di perairan Teluk Klabat. Laporan Akhir Tahun 2007. Kegiatan Program Kompetitif LIPI : 66 hlm.

Juwana, S. dan S. Permadi. 2014. Pembenihan kepiting Scylla serrata dengan pakan berupa nauplii Artemia dan diet formulasi di bak-bak keramik, akrilik dan ekoplas. Oseanologi dan Limnologi di Indonesia 40 (1) : 43-54.

Karim, M. Y. 2007. Pengaruh salinitas dan bobot terhadap konsumsi kepiting bakau (Scylla serrata Forsskal). J. Sains \& Teknologi 7 (2) : 85-92.

Kasry, A. 1986. Pengaruh antibiotika, makanan dan salinitas terhadap kelulus-hidupan dan perkembangan larva kepiting Scylla serrata FORSKAL (Crustacea: Portunidae). Disertasi Doktor Fakultas Pasca Sarjana, Institut Pertanian Bogor.

Keenan, C.P., P.J.F. Davie and D.L. Mann. 1998. A revision of the genus Scylla de Haan, 1883 (Crustacea:Decapoda: Brachyura:Portunidae). The Raffles Bulletin of Zoology 46 (1) : 217-245.

Kementerian Kelautan dan Perikanan. 2010. Statistik perikanan tangkap Indonesia, 2009. Direktorat Perikanan Tangkap : $134 \mathrm{hlm}$. 
Kementerian Kelautan dan Perikanan. 2018. Produktifitas Perikanan Indonesia pada: Forum Merdeka Barat 9, Kementerian Komunikasi dan Informatika : $49 \mathrm{hlm}$.

Mann, D.L., T. Asakawa, M. Pizzutto, C.P. Keenan and L.J. Brock. 2001. Investigation of an Artemia-based diet for larvae of the mud crab Scylla serrata. Asian Fisheries Science 14: 175-184.

Mardjono, M. and M. Arifin. 1993. Pemeliharaan larva kepiting dengan tingkat kepadatan yang berbeda. Laporan tahunan BBAP 1992-1993 : 92-100.

Mwaluma, J. 2002. Pen culture of the mud crab Scylla serrata in Mtwapa mangrove system, Kenya. Westren Indian Ocean J. Mar. Sci. 1 (2) : 127-133.

Nghia, Truong Trong, Mathieu Wille, Tran Cong Binh, Hoang Phuoc Thanh, Nguyen Van Danh and Patrick Sorgeloos. 2007. Improved techniques for rearing mud crab Scylla paramamosain (Estampador 1949) larvae. Aquaculture Research 38: 1539-1553.

Ong, K. S. 1964. The early development of Scylla serrata reared in the laboratory. Proc. Indo-Pacific Fisheries Council 11: 135-146.

Ong. K.S. 1966. Observation on the post larval life history of Scylla serrate (Forksal), reread in the laboratory. Malaysia. Journal Agriculture 45 : 429-443.

Ponat, A. and D. Adelung. 1983. Studies to establish an optimal diet for Carcinus maenas. III. Vitamin and quantitative lipid requirements. Mar. Biol. 74 : 275-279.

Purwati, P., N. Dhewani dan Susetiono. 2009. Kepiting bakau untuk mata pencaharian. Coral Reef Rehabilitation and Management Program, Lembaga Ilmu Pengetahuan Indonesia (COREMAP II-LIPI), Jakarta : $58 \mathrm{hlm}$.

Purwati. P., Suyarso, Y.I.Ulumudin dan S. Permadi. 2012. Ketahanan kepiting bakau di Pesisir Utara Jawa. Laporan Akhir Tahun 2012. Pusat Penelitian Oseanografi LIPI, Jakarta : 44 hlm.

Pratama, I.S., S. Juwana dan S. Permadi. 2016. Penetapan Kadar Kalsium dalam Pakan Formulasi untuk Zoea Awal Kepiting Scylla Paramamosain. Oseanologi dan Limnologi di Indonesia 1(3): 81-90.

Quinitio, E.T., F.D. Parado-Estepa, O.M. Millamena, E. Rodriguez and E. Borlongan. 2001. Seed production of mud crab Scylla serrata juveniles. Asian Fisheries Science 14: 161-174.

Rabbani, A.G. and C. Zeng. 2005. Effects 
of tank colour on larval survival and development of mud crab Scylla serrata (Forskal). Aquaculture Research 36 (11): 1112-1119.

Rodriguez, E.M., Fe D Parado-Estepa and E.T. Quinitio.2007. Extension of nursery culture of Scylla serrata (Forsskal) juveniles in net cages and ponds. Aquaculture Research 38: 1588-1592.

Rusdi, I. 2005. Pemeliharaan larva kepiting bakau (Scylla paramamosain) dengan warna bak berbeda. Seminar Nasional Tahunan Hasil Penelitian Perikanan dan Kelautan : 157161.

Rusdi, I. dan A. Hanafi. 2002. Pembesaran krablet kepiting bakau Scylla paramamosain asal hatchery di lahan mangrove. Prosiding Seminar Riptek Kelautan Nasional : 52-56.

Rusdi, I. dan M.Y. Karim . 2006. Salinitas optimum bagi sintasan dan pertumbuhan crablet kepiting bakau (Scylla paramamosain). J. Sains \& Teknologi 6 (3): 149157.

Sayegh, F.A.Q., N. Radi and D.J.S. Montagnes. 2007. Do strain differences in microalgae alter their relative quality as a food for the rotifer Brachionus plicatilis?. Aquaculture 273: 665-678.

Shelley, C. 2008. Capture-based aquaculture of mud crabs (Scylla spp.). In: A. Lovatelli and P.F. Holthus (Eds.) Capture-Based Aquaculture. Global Overview. FAO Fisheries Technical Paper, No. 508. Rome : 255-269.

Subagio, H. 2002. Pengaruh perbedaan kualitas pakan terhadap perkembangan ovarium kepiting bakau (Scylla serrata). Neptunus 9 (1): 1-8.

Susanto, B., K. Suwirya, I. Setyadi dan Zafran. 2006. Perbaikan teknik produksi benih kepiting bakau (Scylla paramamosain) di Balai Besar Riset Perikanan Budidaya Laut, Gondol-Bali. Prosiding Seminar Nasional Perikanan, $U G M$ : (Abstrak).

Thirunavukkarasu., N, Sheeba Anitha Nesakumari and C, A.Shanmugam. 2014. Larval rearing and production ofmud crab Scylla tranquebarica (Fabricius, 1798). International Journal of Fisheries and Aquatic Studies 2 (2): 19-25.

Trino, A.T., O.M. Millamena and C. Keenan. 1999. Commercial evaluation of monosex pond culture of the mud crab Scylla species at three stocking densities in the Philippines. Aquaculture 174: 109-118.

Trino, A.T., O.M. Millamena and C.P. Keenan. 2001. Pond culture of mud crab Scylla serrata (Forskal) fed formulated diet 
with or without vitamin and mineral supplements. Asian Fisheries Science 14: 191-200.

Trino, A.T. and E.M. Rodriguez. 2001. Mud crab fattening in ponds. Asian Fisheries Science 14: 211-216.

Vu-anh, T.; A. Anderson; J. Luong-van; C. Shelley and G. Allan. 2006. Apparent digestibility of some nutrient sources by juvenile mud crab, Scylla serrata (Forskal 1775). Aquaculture Research 37: 359-365.

Wahyuni, I.S. $1985 . \quad$ Percobaan penetasan dan pembesaran larva kepiting bakau, Scylla serrata (FORSKAL). Laporan Penelitian Laut 32: 89-92.

Widodo, A.F., Sulaiman dan Muslimin. 2010. Laju pemangsaan kepiting bakau (Scylla serrata) terhadap pakan alami rotifera (Branchionus sp). Prosiding Forum Inovasi Teknologi Akuakultur : 139-144.
Yan, Dong-Chun, Feng, Shu-Ying, Jie Huang, and Dong, ShuangLin. 2007. Rotifer cellular membranes bind to white spot syndrome virus (WSSV). Aquaculture 273: 423-426.

Yatsuzuka, K. 1962. Studies on the artificial rearing of the larval brachyura, especially of the larval blue-crab, Neptunus pelagicus Linnaeus. Reports of the Usa Marine Biological Station. Faculty of Literature and Science. Kochi University, Japan, 9 (1): 1-4.

Yi, Soon-Kil; Lee, So-Gwang and Lee, Jeong-Mee. 2009. Preliminary study of seed production of the Micronesian mud crab Scylla serrata (Crustacea: Portunidae) in Korea. Ocean and Polar Research 31(3): 257-264.

Yunus, A. Taufik, I. Rusdi dan D. Makatutu. 1994. Percobaan pemeliharaan larva kepiting bakau, Scylla serrata pada berbagai tingkat salinitas. Jurnal Penelitian Budidaya Pantai 10 (3) 31-38. 